\section{REFERENCES}

Abood, L. G. (1955). Proc. Soc. exp. Biol., N.Y., 88, 688. Aldridge, W. N. (1957). Biochem. J. 67, 423.

Aldridge, W. N. \& Cremer, J. E. (1955). Biochem. J. 61, 406.

Andrejew, A. \& Rosenberg, A. J. (1956). C.R. Soc. Biol., Paris, 150, 639.

Berger, L., Slein, M. W., Colowick, S. P. \& Cori, C. F. (1946). J. gen. Physiol. 29, 379.

Blicke, F. F. \& Smith, F. D. (1929). J. Amer. chem. Soc. 51, 3479.

Brody, T. M. \& Bain, J. A. (1954). J. Pharmacol. 110, 148.

Chance, B. \& Hollunger, G. (1957). J. Amer. chem. Soc. 79, 2970.

Chance, B. \& Williams, G. R. (1955). Nature, Lond., 175, 1120.

Christie, G. S. \& Judah, J. D. (1954). Proc. Roy. Soc, B. 142, 241.

Cooper, C. \& Lehninger, A. L. (1957). J. biol. Chem. 224, 561.

Dickens, F. \& Salmony, D. (1956). Biochem. J. 64, 645.

Fiske, C. H. \& Subbarow, Y. (1925). J. biol. Chem. 66, 375.

Hoch, F. L. \& Lipmann, F. (1954). Proc. nat. Acad. Sci., Wash., 40, 909.

Krishnan, P. S. (1949). Arch. Biochem. 20, 261.
Lardy, H. A. (1955). 3rd Int. Congr. Biochem., Brussels, p. 287.

Lardy, H. A. \& Wellman, H. (1953). J. biol. Chem. 201, 357.

Lee, K. H. \& Eiler, J. J. (1951). Science, 114, 393.

Loomis, W. F. \& Lipmann, F. (1948). J. biol. Chem. 173, 807.

Maley, G. F. \& Lardy, H. A. (1955). J. biol. Chem. 215, 377.

Nesmejanow, A. N. \& Freidlina, R. Ch. (1934). Ber. dtsch. chem. Ges. 67, 735.

Parker, V. H. (1958). Biochem. J. 69, 306.

Peters, R. A. (1955). Johns Hopk. Hosp. Bull. 97, 1.

Potter, V. R. \& Recknagel, R. O. (1951). Phosphorus Metabolism, vol. 1, p. 377. Baltimore: Johns Hopkins Press.

Robinson, H. W. \& Hogden, C. G. (1940). J. biol. Chem. 135, 709.

Siekevitz, F. \& Potter, V. R. (1953). J. biol. Chem. 201, 1.

Slater, E. C. (1953). Nature, Lond., 172, 975.

Stoner, H. B. \& Threlfall, C. J. (1958). 69, 376.

Terner, C. (1954). Biochem. J. 56, 471.

van der Kerk, G. J. M. \& Luijten, J. G. A. (1956). J. appl. Chem. 6, 49.

Vogel, A. I. (1948). Practical Organic Chemistry. London: Longmans, Green and Co.

Weinbach, E. C. (1954). J. biol. Chem. 210, 545.

Zetterström, R. \& Ernster, L. (1956). Nature, Lond., 178, 1335.

\title{
The Biochemistry of Organotin Compounds
}

\section{EFFECT OF TRIETHYLTIN SULPHATE ON TISSUE PHOSPHATES IN THE RAT}

\author{
By H. B. STONER AND C. J. THRELFALL \\ Unit for Research in Toxicology, M.R.C. Laboratories, Carshalton, Surrey
}

(Received 2 December 1957)

In the preceding paper Aldridge (1958) has shown that trialkyltin compounds interfere with the process of oxidative phosphorylation in liver mitochondria and he has also shown (personal communication) that brain mitochondria are equally sensitive. The toxicity of these compounds to the whole animal has been known for a long time (Jolyet \& Cahours, 1869) and has recently been reinvestigated in this Laboratory (Stoner, Barnes \& Duff, 1955; Barnes \& Stoner, 1958). The parallel investigation of these compounds at different levels of biological organization has led to an attempt, so far unsuccessful, to explain the toxicity in biochemical terms. The main effect of these compounds in vivo is upon the central nervous system, which is also the site of the only significant pathological change, an interstitial oedema confined to the white matter of the brain and spinal cord (Magee, Stoner \& Barnes, 1957). Difficulties in elucidating the biochemical mechanisms of their toxicity have already been encountered. Although liver and brain mitochondria are equally affected in vitro, Cremer (1957), working with tissue slices, found that it was only the uptake of oxygen by slices of nervous tissue which was inhibited whether the triethyltin was added in vitro or injected into the rat before it was killed. This was despite the fact that after the injection of triethyltin there was more in the liver than brain and that the temperature of both was depressed after the injection.

Triethyltin is the most active member of the series in vitro and in vivo and its effects on some phosphate components of rat tissues and on the distribution of injected ${ }^{32} \mathrm{P}$ has now been studied in the whole animal. Triethyltin affects the metabolism of both the nervous system and liver in the rat but the mechanism of the derangement cannot yet be deduced from these results nor can they be readily correlated with the previous findings in vitro.

\section{METHODS}

Male albino rats of the Porton strain (145 $\pm 10 \mathrm{~g}$. body wt.) were used. They were fed either on M.R.C. Diet 41 (Bruce \& Parkes, 1949) or more recently on Diet 41 B (Bruce \& Parkes, 1956) given ad lib. In the experiments on nephrectomized rats both kidneys were removed through a ventral 
incision under ether anaesthesia on the afternoon before the experiment.

Larger rats (250-300 g.) had to be used for the measurement of tissue temperatures. The brain temperature was measured with copper-constantan (Eureka) thermocouples (36 s.w.G.) inserted into the brain under ether anaesthesia on the day before the experiment. The liver temperature was measured and its blood flow assessed by the internal calorimetry method of Grayson (1952), used as described previously (Stoner, 1956) except that the rats were not given oxytetracycline hydrochloride.

Triethyltin sulphate was prepared by Dr G. J. M. van der Kerk (Organisch Chemisch Institut, T.N.O., Utrecht, Holland). For injection it was dissolved in $0.9 \% \mathrm{NaCl}$ and neutralized to give a solution of $5 \mathrm{mg} . / \mathrm{ml}$. The controls received an equivalent volume of $0.9 \% \mathrm{NaCl}$.

Radioactive phosphate ( $\left.{ }^{32} \mathrm{P}\right)$ was obtained from the Radiochemical Centre, Amersham, Bucks, as a solution in sterile isotonic phosphate-buffer ( $\mathrm{pH} 7 ; 1 \mathrm{mg}$. of $\mathrm{P} / \mathrm{ml}$.). It was assayed before use as described by Stoner, Threlfall \& Green (1952) and injected intramuscularly in doses of either 25 or $50 \mu \mathrm{c} / 100 \mathrm{~g}$. body wt.

At intervals after the injection of triethyltin or $0.9 \%$ $\mathrm{NaCl}$ and ${ }^{32} \mathrm{P}$ the rats were anaesthetized with pentobarbitone sodium (Veterinary Nembutal; Abbott Laboratories Ltd.) given intraperitoneally ( $5 \mathrm{mg}$./100 g. body wt.) and the tissues sampled in two ways.

As a routine procedure the chest was opened and a sample of blood collected with a Pasteur pipette after division of the great vessels. Heparin (British Drug Houses Ltd.) was used as an anticoagulant and the plasma was obtained by centrifuging the blood immediately in a plastic tube. The plasma inorganic $P$ was determined after precipitation as $\mathrm{MgNH}_{4} \mathrm{PO}_{4}$ from a trichloroacetic acid extract of the plasma (Stoner et al. 1952). A sample of liver was taken and the brain and spinal cord were dissected out as quickly as possible. Trichloroacetic acid extracts of these tissues were prepared as described by Webster (1954). The precipitate was washed once with $10 \%(\mathrm{w} / \mathrm{v})$ trichloroacetic acid and twice with water. Lipid $\mathbf{P}$ was then extracted by the method of Davidson, Frazer \& Hutchison (1951). The final residue was dried and ashed as described by Webster (1954). The $P$ content of these fractions was determined, in duplicate, by the method of Fiske \& Subbarow (1925). Their radioactivity was determined on the same solutions with an M6 liquid counter (20th Century Electronics Ltd.) attached to conventional scaling apparatus, and the usual corrections were made.

The following modifications were adopted for the fractionation of the acid-soluble $\mathrm{P}$ fraction. For the brain the anaesthetized rat was plunged in liquid $\mathrm{N}_{2}$, the cerebral hemispheres were dissected out when the rat was frozen and the tissue was stored in liquid $\mathrm{N}_{2}$. For the liver, a sample was quickly removed from the anaesthetized rat and frozen in liquid $\mathrm{N}_{2}$.

The liver and brain nucleotides were separated as described by Threlfall (1957) with 6 vol. and 12 vol. of $3 \%$ $(\mathrm{v} / \mathrm{v})$ perchloric acid respectively for extraction and $150 \mathrm{mg}$. and $100 \mathrm{mg}$. of Norit SX30 special charcoal (Haller and Phillips, Ltd. London) for adsorption. Separation was achieved by two-dimensional paper chromatography with the isobutyric acid-aq. $\mathrm{NH}_{3}$ soln. and the acetone-water systems as a routine procedure. This combination of systems ensured the complete separation of the inorganic $P$ from the nucleotide components necessary for determinations of radioactivity. $P$ was estimated by the method of Berenblum \& Chain (1938) as previously described (Threlfall, 1957) and the radioactivity of the isobutanol was determined as above, after the $P$ estimation. The total acid-soluble adenine content of the liver was assessed from the ultraviolet-light-absorption spectrum of suitably diluted perchloric acid extracts.

The blood content of the liver was determined with ${ }^{32} \mathrm{P}$ labelled erythrocytes (Chaplin, 1954). A small volume $(0.25 \mathrm{ml}$.) of labelled blood was injected into a tail vein of a rat under pentabarbitone anaesthesia; after equilibration for about $10 \mathrm{~min}$., samples of blood and liver were taken, extracted with $3 \%(\mathrm{v} / \mathrm{v})$ perchloric acid and their radioactivity was determined.

The water content of the tissues was determined by drying to a constant weight at $105^{\circ}$. The liver was examined histologically in paraffin sections stained with haematoxylin and eosin after fixation in Helly's fluid. Some of the rats used for histological studies were given $0 \cdot 07 \mathrm{mg}$. of colchicine/100 g. body wt. just before the start of the experiment and $4 \mathrm{hr}$. before the rat was killed.

Results are expressed as the mean \pm standard deviation and have been examined statistically by Student's $t$ test as modified by Fisher (1934) for small samples.

The following abbreviations have been used: adenosine mono-, di- and tri-phosphate, AMP, ADP and ATP; di- and tri-phosphopyridine nucleotide, DPN and TPN.

\section{RESULTS}

\section{Toxicity of triethyltin}

The standard dose of triethyltin sulphate used in these experiments was $1.2 \mathrm{mg} . / 100 \mathrm{~g}$. body wt., injected intraperitoneally. This dose is two to three times the $\mathrm{LD}_{50}$ and is always fatal, the survival time being about $48 \mathrm{hr}$. Signs of poisoning appear about $10 \mathrm{~min}$. after the injection. The hind limbs become weak and flaccid and the rat has difficulty in walking. The rat quickly becomes prostrate. After a few hours there is some recovery but this is never complete and is soon replaced by progressive muscular weakness. After $24 \mathrm{hr}$. the rat usually appears moribund. The present experiments were confined to the first $24 \mathrm{hr}$. of the illness. The typical changes in the temperature of the brain and liver and in the hepatic blood flow during this period are shown in Fig. 1. Although triethyltin is not rapidly excreted in the urine, bilateral nephrectomy shortened the survival time so that many of these rats given the standard dose did not survive $24 \mathrm{hr}$. A lower dose was used in some of these experiments.

\section{Effect of triethyltin on the plasma inorganic phosphate level}

In normal rats the plasma inorganic $P$ level rose significantly after the administration of triethyltin (Table 1). After nephrectomy this inorganic $P$ level was high and the difference between the 


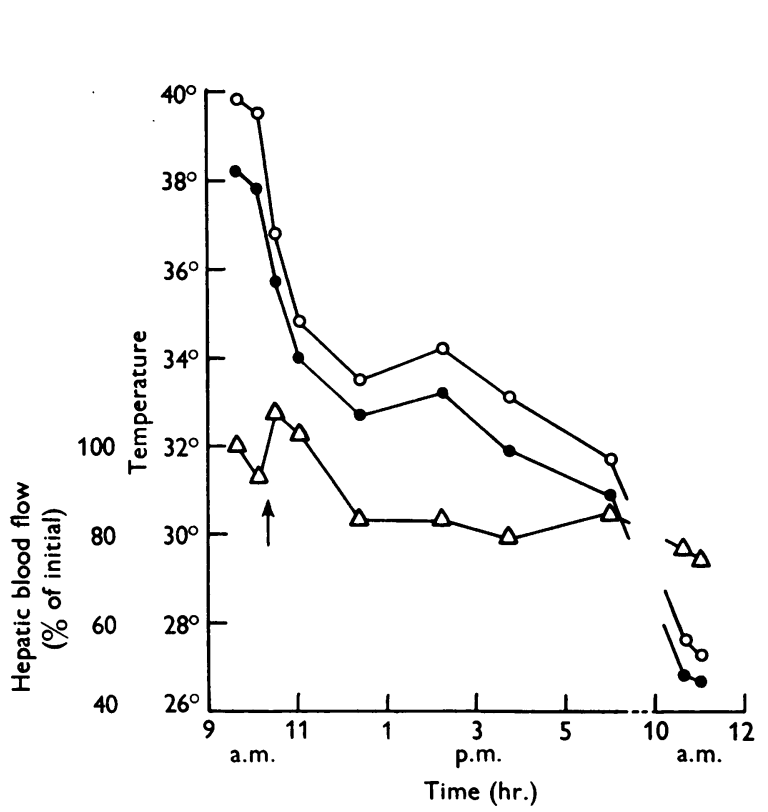

Fig, 1

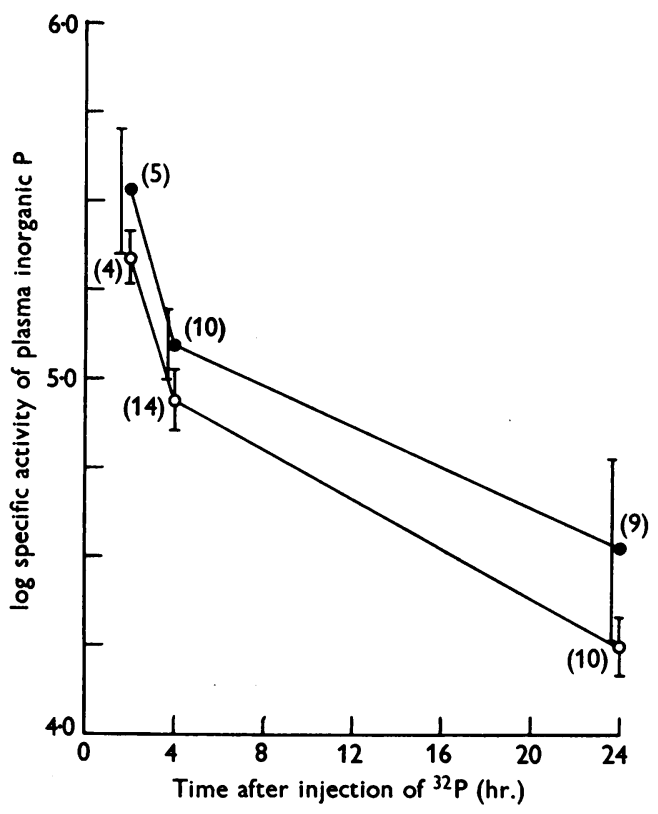

Fig. 2

Fig. 1. Effect of the intraperitoneal injection of $1.2 \mathrm{mg}$. of triethyltin sulphate $/ 100 \mathrm{~g}$. body wt. at the time indicated by the arrow on the temperature of the liver $(O)$ and brain $(O)$ and on the liver blood flow $(\Delta)$. Liver blood flow is expressed as a percentage of the initial level.

Fig. 2. Disappearance of ${ }^{32} \mathrm{P}$ from the plasma of rats (O) given $1 \cdot 2 \mathrm{mg}$. of triethyltin sulphate/100 g. body wt. intraperitoneally $0.75 \mathrm{hr}$. before the intramuscular injection of $50 \mu \mathrm{c}$ of ${ }^{82} \mathrm{P} / 100 \mathrm{~g}$. body wt. and from the plasma of controls $(O)$ given the same dose of ${ }^{32} \mathrm{P}$ and an injection of $0.9 \% \mathrm{NaCl}$ equivalent in volume to the dose of triethyltin. The vertical lines show the S.D. of the mean and the numbers in parentheses show the number of rats examined at each point. The means at 4 and $24 \mathrm{hr}$. after the injection of ${ }^{32} \mathrm{P}$ were significantly different at a level of $P<0.001$ and $P<0.01$ respectively.

Table 1. Effect of triethyltin on the plasma inorganic phosphate level in normal and nephrectomized rats

Triethyltin sulphate $(1.2 \mathrm{mg} . / 100 \mathrm{~g}$. body wt.) was injected intraperitoneally. Bilateral nephrectomy was performed $24 \mathrm{hr}$. before the experiment.

$\begin{array}{lrc}\text { Treatment } & \begin{array}{c}\text { No. of } \\ \text { rats }\end{array} & \begin{array}{c}\text { Plasma inorganic } \\ \text { P (mg. \%) }\end{array} \\ \text { Normal rats } & & \\ \text { Controls } & 19 & 8 \cdot 40 \pm 2 \cdot 27 \\ 2 \mathrm{hr} \text {. after triethyltin } & 5 & 10 \cdot 43 \pm 2 \cdot 12 \\ 4 \mathrm{hr} \text {. after triethyltin } & 10 & 10 \cdot 54 \pm 1 \cdot 62^{*} \\ 24 \mathrm{hr} \text {. after triethyltin } & 4 & 11 \cdot 96 \pm 1 \cdot 94 \dagger \\ \text { Nephrectomized rats } & & \\ \quad \text { Controls } & 13 & 25 \cdot 11 \pm 2 \cdot 47 \\ 4 \mathrm{hr} \text {. after triethyltin } & 6 & 26 \cdot 30 \pm 2 \cdot 07 \\ \text { * Difference from control mean significant at } P<0 \cdot 02 . \\ \dagger \text { Difference from control mean significant at } P<0 \cdot 01 .\end{array}$

control and treated rats was not seen. This suggests that the rise in the plasma inorganic $P$ level after triethyltin in normal rats is due to the associated fall in urine production.

\section{Disappearance of ${ }^{82} \mathrm{P}$ from the plasma}

The rate of disappearance of ${ }^{32} \mathrm{P}$ from the plasma after its intramuscular injection was reduced in rats given triethyltin (Fig. 2). Nephrectomized rats were used to see if this was due to a fall in urinary excretion or reduced ${ }^{32} \mathrm{P}$ uptake by the tissues. In six such rats the specific activity of the plasma inorganic $\mathrm{P} 4 \mathrm{hr}$. after the intramuscular injection of $25 \mu \mathrm{C}$ of ${ }^{32} \mathrm{P} / 100 \mathrm{~g}$. body wt. and $4.75 \mathrm{hr}$. after the standard dose of triethyltin was $151900 \pm 30360$ counts $/ \mathrm{min}$./mg. of $P$. This was higher $(P<0.01)$ than the corresponding level in the plasma of the 13 nephrectomized controls: $109800 \pm 28200$ counts $/ \mathrm{min}$./mg. of $P$. The condition of these rats was very much worse than that of normal rats given the standard amount of triethyltin. The experiment was therefore repeated in seven rats with a lower dose of triethyltin sulphate $(0.3 \mathrm{mg} . / 100 \mathrm{~g}$. body wt. $)$, which produced a similar condition to that in normal rats after the standard dose. Under these conditions the 
specific activity of the plasma inorganic $P$ (148 $300 \pm 44080$ counts $/ \mathrm{min}$./mg. of $P$ ) was still greater $(P<0.05)$ than in the controls.

\section{Penetration of tissue by ${ }^{32} \mathrm{P}$ after administration of triethyltin}

Because of the nature of the lesion produced by triethyltin its effect on the penetration of ${ }^{32} \mathrm{P}$ into the tissues, particularly the brain, is of some interest.

Where the brain was not frozen in situ, data on the specific activity of the total acid-soluble $P$ in the brain and spinal cord and on the plasma inorganic $P$ are available from the same animal. In these experiments the ratio of the specific activity of the total acid-soluble $P$ to that of the plasma inorganic $P$ suggested that entry of ${ }^{32} P$ was hindered by triethyltin, but the differences were not statistically significant (Table 8).

Since cardiac puncture in the anaesthetized rat immediately before immersion in liquid $\mathrm{N}_{2}$ altered

Table 2. Ratio of the specific activity of the total acid-soluble phosphate fraction of the cerebrum in rats treated with triethyltin to that in controls

Triethyltin sulphate $(1.2 \mathrm{mg} . / 100 \mathrm{~g}$. body wt.) was injected intraperitoneally. Controls were given an equivalent volume of $0.9 \% \mathrm{NaCl} ; 50 \mu \mathrm{C}$ of ${ }^{32} \mathrm{P} / 100 \mathrm{~g}$. body wt. was injected intraperitoneally. The corresponding ratios for the specific activity of the inorganic $\mathbf{P}$ of the plasma in a similar group of experimental and control rats are also shown. The number of experimental and control rats in each group is shown in parentheses.

\begin{tabular}{|c|c|}
\hline \multicolumn{2}{|c|}{$\begin{array}{c}\text { Time after } \\
\text { injection (hr.) }\end{array}$} \\
\hline $\begin{array}{l}\text { Triethyltin or } \\
0.9 \% \mathrm{NaCl}\end{array}$ & ${ }^{32} \mathrm{P}$ \\
\hline $\begin{array}{r}\mathbf{4} \cdot 75 \\
24 \cdot 75 \\
24 \cdot 0\end{array}$ & $\begin{array}{r}4 \cdot 0 \\
24 \cdot 0 \\
4 \cdot 0\end{array}$ \\
\hline
\end{tabular}

\begin{tabular}{|c|c|}
\hline \multicolumn{2}{|c|}{$\begin{array}{l}\text { Specific activity ratios } \\
\text { (triethyltin/control) }\end{array}$} \\
\hline $\begin{array}{l}\text { Cerebrum } \\
\text { total } \\
\text { acid-soluble P }\end{array}$ & $\begin{array}{c}\text { Plasma } \\
\text { inorganic P }\end{array}$ \\
\hline $\begin{array}{l}1.53(3 / 6) \\
1 \cdot 11(7 / 6) \\
0 \cdot 85(6 / 6)\end{array}$ & $\begin{array}{l}1.42(10 / 14) \\
2 \cdot 21(9 / 10) \\
2 \cdot 76(8 / 8)\end{array}$ \\
\hline
\end{tabular}

the $P$ levels in the brain the specific activity of the plasma inorganic $P$ could not be compared with the activity of the brain fractions in the same animal. However, if it be assumed that the specific activity of the plasma inorganic $P$ in these rats was the same as in the previous group, the ratios of the specific activity of the total acid-soluble $P$ of the cerebrum in the triethyltin-treated rats and their controls can be compared with the corresponding ratios for the plasma inorganic $P$ (Table 2). If the passage of ${ }^{82} \mathrm{P}$ into the brain was unaltered by triethyltin these ratios would be the same. The results indicate that although ${ }^{32} \mathrm{P}$ penetration during the early stages of triethyltin poisoning was in accordance with the plasma level, it was reduced over a $24 \mathrm{hr}$. period. The reduced entry of ${ }^{32} \mathrm{P}$ was specially marked when it was examined between 20 and $24 \mathrm{hr}$. after the injection of triethyltin, i.e. when the rat was severely affected.

The specific activity of the cerebral inorganic $P$ in nephrectomized rats given $\mathbf{0 . 3} \mathrm{mg}$. of triethyltin sulphate/100 g. body wt. was compared with that in nephrectomized controls (Table 3) as the inorganic $\mathrm{P}$ levels in the plasma and cerebrum of these two groups were the same. The specific activity of the inorganic $P$ of the plasma of the treated rats was $35 \%$ higher than in the controls (see above), but its entry into the total acid-soluble and inorganic $P$ fractions of the cerebrum during a $4 \mathrm{hr}$. period was reduced by $28 \%$.

The entry of ${ }^{32} \mathrm{P}$ into the liver appeared unaffected by triethyltin, judging by the specific activity of its total acid-soluble $P$ relative to that of the plasma inorganic $P$ (Table 10).

\section{Effect of triethyltin on distribution of tissue phosphate}

There was little change in the three main $P$ fractions of the brain and spinal cord until $24 \mathrm{hr}$. after the injection of triethyltin, when most of the levels, expressed on a wet-weight basis, had decreased (Table 4). By this time the water content

Table 3. Effect of triethyltin on the radioactivity of the total acid-soluble and inorganic phosphate fractions of the cerebrum in nephrectomized rats

All rats were given $25 \mu \mathrm{C}$ of ${ }^{32} \mathrm{P} / 100 \mathrm{~g}$. body wt. intramuscularly $4 \mathrm{hr}$. before they were killed. Rats treated with triethyltin sulphate were given $0.3 \mathrm{mg} . / 100 \mathrm{~g}$. body wt. intraperitoneally and the controls an equivalent volume of $0.9 \%$ $\mathrm{NaCl} 4 \cdot 75 \mathrm{hr}$. before they were killed.

\begin{tabular}{|c|c|c|c|c|c|c|}
\hline \multirow[b]{2}{*}{ Treatment } & \multirow[b]{2}{*}{$\begin{array}{l}\text { No. of } \\
\text { rats }\end{array}$} & \multicolumn{2}{|c|}{$\begin{array}{c}\text { Cerebrum } \\
\text { (mg. of } \mathrm{P} / \mathrm{g} \text {. wet wt.) }\end{array}$} & \multicolumn{2}{|c|}{$\begin{array}{l}\text { Specific activity (S.A.) } \\
\text { (counts/min./mg. of P) }\end{array}$} & \multirow[b]{2}{*}{$\frac{10^{3}}{\text { S.A. of total acid-soluble } P}$} \\
\hline & & $\begin{array}{c}\text { Total } \\
\text { acid-soluble P }\end{array}$ & Inorganic $\mathrm{P}$ & $\begin{array}{c}\text { Total } \\
\text { acid-soluble P }\end{array}$ & Inorganic $\mathbf{P}$ & \\
\hline Controls & 5 & $0 \cdot 83 \pm 0 \cdot 25$ & $0 \cdot 29 \pm 0 \cdot 12$ & $7166 \pm 1410$ & $8568 \pm 1500$ & $1206 \pm 150$ \\
\hline \multirow[t]{2}{*}{ Triethyltin } & 5 & $0.96 \pm 0.62$ & $0 \cdot 36 \pm 0 \cdot 40$ & $5162 \pm 830^{*}$ & $6148 \pm 980 \dagger$ & $1198 \pm 132$ \\
\hline & \multicolumn{3}{|c|}{ Ratio triethyltin/control } & 0.72 & 0.72 & 0.99 \\
\hline
\end{tabular}

* Significantly different from control mean at $P<0 \cdot 05$.

$\dagger$ Significantly different from control mean at $P<0 \cdot 02$. 


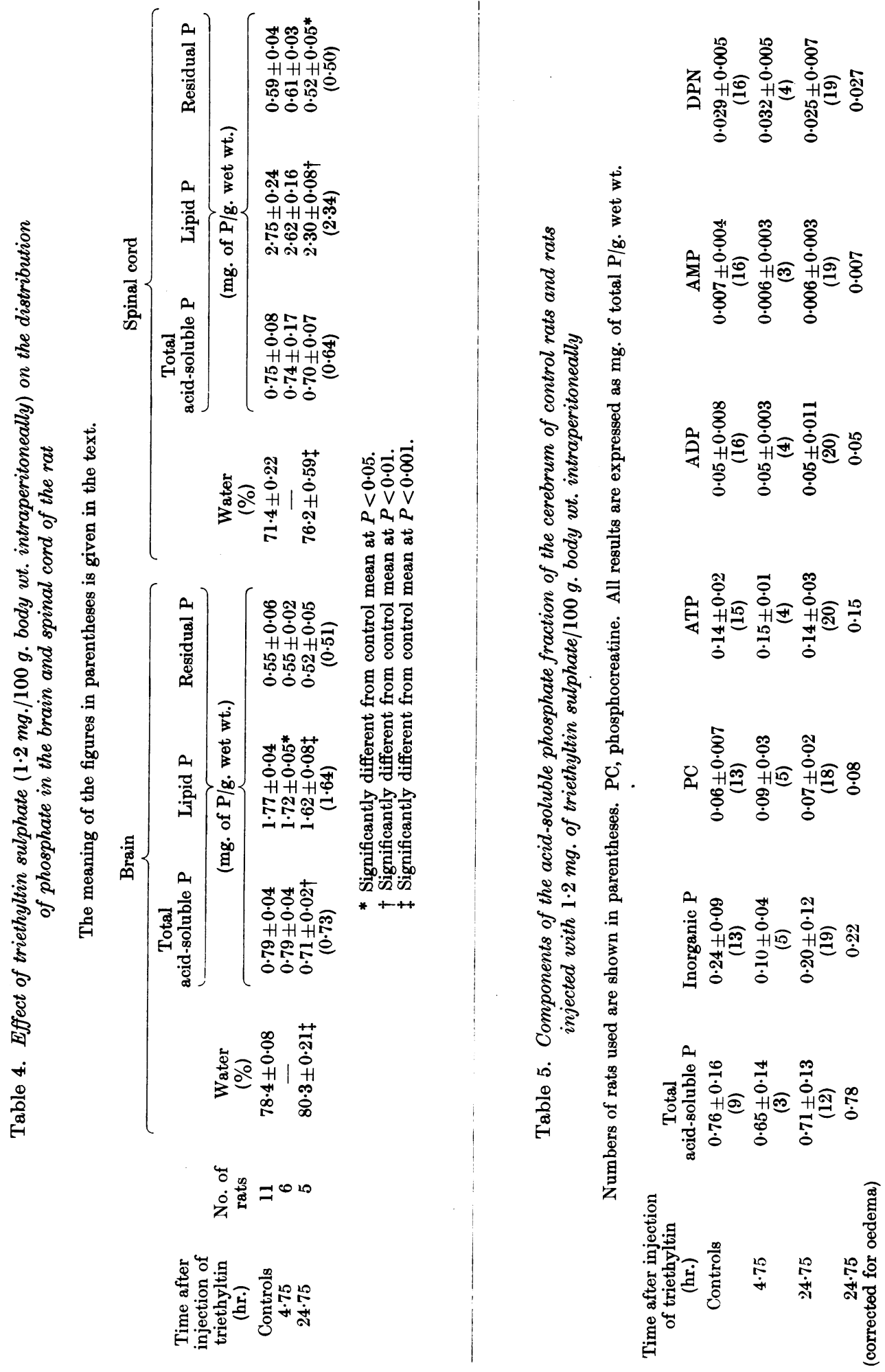


of the brain and spinal cord had increased significantly, owing to the addition of an ultrafiltrate of plasma to these tissues without change in their solid elements (Magee et al. 1957). Values (shown in parenthesis in Table 4) for the $P$ fractions $24 \mathrm{hr}$. after the administration of triethyltin can therefore be calculated from the control levels, as described in the Appendix of Magee et al. (1957). Their agreement with the experimental values suggests that the observed changes were due to the oedema.

In the further fractionation of the acid-soluble $P$ fraction of the cerebrum (Table 5) the variability of the inorganic $P$ fraction could not be attributed to changes in labile $\mathbf{P}$ compounds. Although the samples were freed from bone as carefully as possible this variation is thought to be due to the presence of undetected spicules which had contaminated the cerebrum during its dissection from the frozen head. Triethyltin had no significant effect on the levels of the other components of this fraction even when allowance was made for the cerebral oedema. There was no loss of phosphocreatine or ATP even in rats killed on the point of death.

The water content of the liver was unaffected by triethyltin and $4 \mathrm{hr}$. after its administration the wet weight of the liver/100 g. body wt. was the same as in the controls. The blood content of the liver in the rats treated with triethyltin did not differ from that in the controls and was similar to that found by others with different methods (Caster, Simon \& Armstrong, 1955). The lipid and residual $P$ fractions were unaltered during the first few hours after the injection of triethyltin, but the acid-soluble $P$ level rose significantly (Table 6). The latter is seen also in another group of rats in Table 7. There, although the rise in the acidsoluble $\mathbf{P}$ fraction was similar, the control level was much lower. The difference in the control levels could not be explained on technical grounds and may be due to differences in the animals due either to the change in diet or the different season of the year in which they were obtained. The increase in the total acid-soluble $P$ level after triethyltin could not be accounted for by the rise in the plasma inorganic $\mathrm{P}$ but corresponded with the increases in the ATP and ADP levels, which reached a maximum about this time (Table 7). Further evidence for an increase in the liver nucleotide content $4 \mathrm{hr}$. after the injection of triethyltin was obtained by examining the u.v.-light-absorption spectra of the liver extracts. The extinction (1 g. $/ \mathrm{ml}$.) at $260 \mathrm{~m} \mu$ was $125 \pm 7 \cdot 4$ for six control extracts and $151 \pm 7 \cdot 4$ for extracts from six treated rats. This difference is highly significant $(P<0.001)$ and, with no chromatographic evidence of a decrease in the nonadenine nucleotides, suggests an increase in the nucleotide content of the liver. With a value of $1.47 \times 10^{4}$ for the molar-absorbency index (Bock, Ling, Morell \& Lipton, 1956), the increase in extinction at $258 \mathrm{~m} \mu$ represents an increase of $238 \mu \mathrm{g} . / \mathrm{g}$. in the adenine content of the liver, more than sufficient to account for the observed increase in adenine nucleotide and total $P$ levels. The progressive nature of the change in the adenine nucleotide of the acid-soluble fraction of the liver is shown in Table 7. This change did not extend to the DPN or TPN fractions but was reflected in the increase in the uridine triphosphate and guanosine triphosphate levels.

Histological examination of the liver revealed a wave of mitoses occurring about $4 \mathrm{hr}$. after the injection of triethyltin. This was the only abnormal feature seen in these acute experiments otherwise the appearance of the liver was normal, as after much longer periods of exposure to triethyltin (Magee et al. 1957).

\section{Effect of triethyltin on distribution of ${ }^{32} \mathrm{P}$ in the nervous system}

To circumvent difficulties arising from the unequal penetration of ${ }^{32} \mathrm{P}$ into the nervous systems of control and experimental rats the specific activities of the $P$ fractions within the tissue have been expressed as fractions of the specific activity of the total acid-soluble $P$ as done by Webster (1954). The pattern of incorporation of ${ }^{32} \mathrm{P}$ in the spinal cord of these young rats differed from that found by Webster (1954) in adult hens. This was not due to the slight differences in analytical technique, since when this technique was applied to adult hens the results agreed with those of Webster.

Table 6. Effect of triethyltin sulphate $(1 \cdot 2 \mathrm{mg} . / 100 \mathrm{~g}$. body wt. injected intraperitoneally) on distribution of phosphate in the liver of the rat

\begin{tabular}{|c|c|c|c|c|}
\hline \multirow{2}{*}{$\begin{array}{l}\text { Time after } \\
\text { injection of } \\
\text { triethyltin } \\
\text { (hr.) }\end{array}$} & \multirow{2}{*}{$\begin{array}{l}\text { No. of } \\
\text { rats }\end{array}$} & $\begin{array}{c}\text { Total } \\
\text { acid-soluble P }\end{array}$ & Lipid P & Residual $\mathbf{P}$ \\
\hline & & \multicolumn{3}{|c|}{ (mg. of $\mathrm{P} / \mathrm{g}$. wet wt.) } \\
\hline $\begin{array}{c}\text { Controls } \\
2 \cdot 75 \\
4.75\end{array}$ & $\begin{array}{r}10 \\
5 \\
7\end{array}$ & $\begin{array}{l}1 \cdot 19 \pm 0.06 \\
1 \cdot 30 \pm 0.07^{*} \\
1 \cdot 28 \pm 0.04^{*}\end{array}$ & $\begin{array}{l}1 \cdot 25 \pm 0.09 \\
1 \cdot 26 \pm 0 \cdot 12 \\
1 \cdot 29 \pm 0.04\end{array}$ & $\begin{array}{l}1 \cdot 29 \pm 0.08 \\
1 \cdot 31 \pm 0.08 \\
1 \cdot 34 \pm 0.05\end{array}$ \\
\hline
\end{tabular}




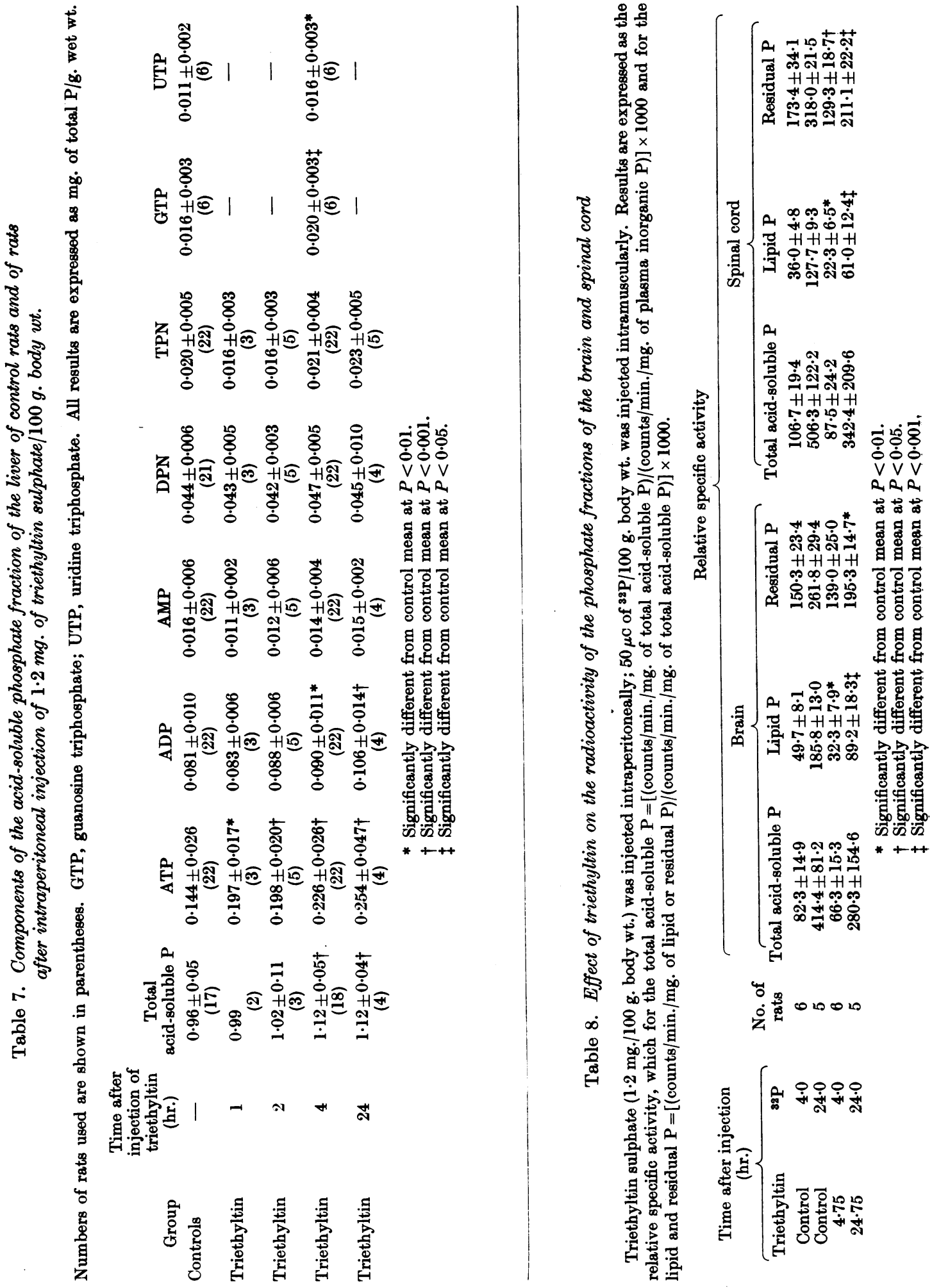


Triethyltin depressed the relative specific activities of the lipid and residual $P$ fractions in both brain and spinal cord, the changes being most marked in the latter (Table 8). Although the relative specific activity of the total acid-soluble $\mathbf{P}$ was lower in the rats given triethyltin its variability was such that the differences were not statistically significant. Within this fraction distribution of ${ }^{32} \mathrm{P}$ in the energy-rich phosphates (phosphocreatine, ATP and ADP) of the cerebrum was unaffected by triethyltin even when ${ }^{32} P$ was not given until $20 \mathrm{hr}$. after the injection of triethyltin, i.e. when the rat was extremely ill (Table 9). The incorporation of ${ }^{82} \mathrm{P}$ into the guanosine and uridine triphosphates of the cere- brum was also unaffected by triethyltin in the few experiments in which they were measured. The only striking change was the reduction in the relative activity of the DPN. The concentrations of DPN and adenosine monophosphate in the cerebrum are very low and their rate of labelling is slow so that reliable data could only be obtained $24 \mathrm{hr}$. after the injection of ${ }^{32} \mathrm{P}$.

\section{Effect of triethyltin on distribution of ${ }^{32} \mathrm{P}$ in the liver}

The distribution of ${ }^{32} \mathrm{P}$ within the liver has been expressed in terms of relative specific activity as for the brain. The relative specific activities of the total acid-soluble $P$ and its constituents were unaltered by triethyltin (Tables 10 and 11). As in

Table 9. Effect of triethyltin on the relative specific activity of the components of the acid-soluble phosphate fraction of the cerebrum of the rat

Triethyltin sulphate (1.2 mg./100 g. body wt.) was injected intraperitoneally; $50 \mu \mathrm{C}$ of ${ }^{32} \mathrm{P} / 100 \mathrm{~g}$. body wt. was injected intramuscularly. Relative specific activity $=$ (specific activity of total $\mathbf{P}$ of compound/specific activity of total acid-soluble P) $\times 1000$. PC, phosphocreatine.

Time after injection

(hr.)

$\begin{array}{cr}\text { Triethyltin } & 32 \mathrm{P} \\ \text { Control } & \mathbf{4 \cdot 0} \\ \text { Control } & \mathbf{2 4 \cdot 0} \\ \mathbf{4} \cdot 75 & \mathbf{4 \cdot 0} \\ \mathbf{2 4 \cdot 0} & \mathbf{4 \cdot 0} \\ \mathbf{2 4 \cdot 7 5} & \mathbf{2 4 \cdot 0}\end{array}$

No. of
rats
6
6
3
6
7

Relative specific activity

\begin{tabular}{cccccc}
\hline Inorganic P & PC & ATP & ADP & AMP & DPN \\
$1480 \pm 330$ & $1140 \pm 610$ & $910 \pm 350$ & $780 \pm 110$ & - & - \\
$1100 \pm 160$ & $1120 \pm 390$ & $1020 \pm 140$ & $920 \pm 160$ & $1190 \pm 490$ & $680 \pm 70$ \\
$2010 \pm 310$ & $1230 \pm 200$ & $910 \pm 90$ & $630 \pm 100$ & - & - \\
$1960 \pm 570$ & $900 \pm 220$ & $828 \pm 170$ & $600 \pm 170$ & - & - \\
$1334 \pm 180^{*}$ & $1290 \pm 270$ & $980 \pm 170$ & $880 \pm 150$ & $920 \pm 230$ & $360 \pm 220 \dagger$
\end{tabular}

* Significantly different from control mean at $P<0.05$.

$\dagger$ Significantly different from control mean at $P<0 \cdot 01$.

Table 10. Effect of triethyltin on the radioactivity of the phosphate fractions of the liver

Triethyltin sulphate $\left(1.2 \mathrm{mg} . / 100 \mathrm{~g}\right.$. body wt.) was injected intraperitoneally; $50 \mu \mathrm{C}$ of ${ }^{32} \mathrm{P} / 100 \mathrm{~g}$. body wt. was injected intramuscularly. Results are expressed as the relative specific activity, which for the total acid-soluble $P=[(\mathrm{counts} / \mathrm{min}$. $]$ mg. of total acid-soluble $\mathrm{P}) /($ counts $/ \mathrm{min} . / \mathrm{mg}$. of plasma inorganic $\mathrm{P})] \times 1000$ and for the lipid and residual $P=[($ counts $/$ min./mg. of lipid or residual P)/(counts/min./mg. of total acid-soluble P)] $\times 1000$.

Time after injection

$\begin{array}{cc}\text { Triethyltin } & \text { 32P } \\ \text { Controls } & 2 \\ \text { Controls } & 4 \\ 2 \cdot 75 & 2 \\ 4 \cdot 75 & 4\end{array}$

No. of
rats
4
6
4
7

Relative specific activity

* Significantly different from control mean at $P<0.001$.

$\begin{array}{cc}\text { Lipid P } & \text { Residual P } \\ 138 \cdot 7 \pm 31 \cdot 7 & 40 \cdot 8 \pm 6 \cdot 7 \\ 368 \cdot 1 \pm 59 \cdot 9 & \mathbf{7 5 \cdot 5} \pm 5 \cdot 6 \\ 101 \cdot 2 \pm 31 \cdot 7 & \mathbf{4 5 \cdot 4} \pm \mathbf{8} \cdot 5 \\ \mathbf{2 5 7 \cdot 1} \pm 34 \cdot 4^{*} & \mathbf{8 7 \cdot 1} \pm \mathbf{7} \cdot 0 \dagger\end{array}$

$\dagger$ Significantly different from control mean at $P<0.01$.

Table 11. Effect of triethyltin on the relative specific activity of the nucleotides in the liver of the rat

Rats were killed $1 \mathrm{hr}$. after $25 \mu \mathrm{C}$ of ${ }^{32} \mathrm{P} / 100 \mathrm{~g}$. body wt. had been injected intramuscularly and $4 \mathrm{hr}$. after the intraperitoneal injection of either $1.2 \mathrm{mg}$. of triethyltin sulphate $/ 100 \mathrm{~g}$. body wt. or an equivalent volume of $0 \cdot 9 \% \mathrm{NaCl}$.

Relative specific activity

\begin{tabular}{|c|c|c|c|c|c|c|}
\hline \multirow[b]{2}{*}{ Group } & \multirow{2}{*}{$\begin{array}{l}\text { No. of } \\
\text { rats }\end{array}$} & \multirow{2}{*}{ ATP } & \multirow[b]{2}{*}{ ADP } & & \multirow[b]{2}{*}{ TPN } \\
\hline & & & & AMP & DPN & \\
\hline rtin & $\begin{array}{l}6 \\
6\end{array}$ & $\begin{array}{l}1504 \cdot 2 \pm 576 \cdot 5 \\
1326 \cdot 1 \pm 204 \cdot 9\end{array}$ & $\begin{array}{l}1016 \cdot 5 \pm 100 \cdot 3 \\
1153 \cdot 9 \pm 150 \cdot 9\end{array}$ & $\begin{array}{l}713 \cdot 3 \pm 129 \cdot 2 \\
595 \cdot 0 \pm 117 \cdot 1\end{array}$ & $\begin{array}{r}95 \cdot 1 \pm 18 \cdot 4 \\
114 \cdot 8 \pm 30 \cdot 8\end{array}$ & $\begin{array}{l}332 \cdot 7 \pm 120 \cdot 6 \\
291 \cdot 2 \pm 84 \cdot 5\end{array}$ \\
\hline
\end{tabular}


the nervous system the incorporation of ${ }^{32} \mathrm{P}$ into the lipid $P$ fraction was reduced but there was an increase in the relative activity of the residual $P$ fraction (Table 10).

\section{DISCUSSION}

The striking pathological finding in triethyltin poisoning is the interstitial oedema of the central nervous system without visible damage to the nerve cells or demyelination of nerve tracts. Therefore it was perhaps rather surprising to find the entry of ${ }^{32} \mathrm{P}$ into the nervous system impeded by triethyltin, although this confirms previous results on the penetration of sulphanilamide after triethyltin (Magee et al. 1957). As this defect is to some extent correlated with the general condition of the rat it might be related to a reduced circulation of blood through the tissues with a poor distribution of ${ }^{32} \mathrm{P}$ to them. However, its entry into the liver was unaffected, and this is unlikely to be the whole explanation for if any significant cerebral ischaemia existed the phosphocreatine and ATP levels would have fallen, and such falls were never found. Furthermore, there was no evidence that triethyltin affected hepatic blood flow during the period under discussion and the flow through the brain is usually better preserved than through the liver (Stoner, 1954). The difference may be due to a failure in a transport mechanism whereby the ${ }^{32} \mathrm{P}$ crosses some 'membrane' into the central nervous system. Further work is planned on these problems and it may be wrong to seek quite such a specific explanation. After triethyltin the temperature falls in both the brain and the liver and the reduced penetration of ${ }^{32} \mathrm{P}$ into the brain could be due to the blood-brain barrier being more sensitive to temperature change than the blood-liver barrier.

Once the ${ }^{32} \mathrm{P}$ has entered the brain its distribution to the energy-rich phosphates, phosphocreatine, ATP and ADP, appears unimpaired. From previous work with ${ }^{32} \mathrm{P}$ (Stoner, 1950; Stoner et al. 1952) it seems likely that in a tissue in a living animal where oxidative phosphorylation is occurring the incorporation of ${ }^{32} \mathrm{P}$ into these compounds is so rapid that partial inhibition of the process would not be seen in such results. This is particularly true for the brain because of the slow rate of entry of the isotope (Streicher, 1956). 2:4Dinitrophenol strongly inhibits oxidative phosphorylation (Loomis \& Lipmann, 1948) in vitro, but fatal doses of the related 3:5-dinitro-o-cresol have no effect on the specific activity of ${ }^{32} \mathrm{P}$ in the energy-rich phosphates of rat skeletal muscle in vivo (Stoner et al. 1952). Nevertheless, the tissue levels of these phosphates are reduced in rats poisoned with 3:5-dinitro-o-cresol, particularly in the brain (Parker, 1954), showing that it does inter- fere with their metabolism. Rats given triethyltin showed no change in the amount of phosphate in the various fractions of the central nervous system, and the findings in the present experiments would not have suggested that triethyltin inhibited oxidative phosphorylation in vitro. In individual experiments the phosphocreatine and ATP levels in the cerebrum were often higher than in the controls, suggesting that the reduced activity of the rat after triethyltin had a protective effect on the levels of these compounds, as with the narcotics discussed by Buchel \& McIlwain (1950).

The observed effects of triethyltin on the incorporation of ${ }^{32} \mathrm{P}$ into the nervous system, namely the reduction in the relative specific activities of the DPN, lipid $\mathrm{P}$ and residual $\mathrm{P}$ fractions, suggest interference with the utilization of chemical energy. Although ${ }^{32} \mathrm{P}$ can be incorporated into the energy-rich phosphates its further distribution is impaired. In this the action of triethyltin resembles that of sodium pentobarbital (Dawson \& Richter, 1950) and chlorpromazine (Ansell \& Dohmen, 1956). This similarity may be merely a reflexion of the fall in tissue temperature produced by all those substances.

If all the changes discussed so far are secondary to the fall in tissue temperature attention is focussed on the mechanism of that hypothermia. With triethyltin this will be complex. As it is a peripheral vasodilator (Stoner et al. 1955) heat loss will be accelerated and not all of the effect will be due to decreased heat production. It should also be recalled that when heat loss is reduced by raising the environmental temperature to $30^{\circ}$ the symptoms of triethyltin poisoning in the rat are exaggerated (Stoner et al. 1955). The way in which energy is liberated as heat during oxidation in the tissues is incompletely understood, as is the way in which this process is controlled. Metabolic inhibitors fall into two groups, according to whether they lower or raise body temperature, and their effect on tissue nucleotides may well be determined by this. With triethyltin, chlorpromazine and the barbiturates the fall in tissue temperature, by lowering the demand for metabolic energy, may allow compensatory mechanisms to preserve the levels of phosphocreatine and ATP. For 3:5-dinitro-o-cresol this compensation cannot be effective because of the rise in tissue temperature (Stoner, 1956).

The interpretation of the action of triethyltin in the whole animal is further complicated by the changes in the liver, where the concentration of triethyltin is much higher than in the brain (Cremer, 1957). The incorporation of ${ }^{32} \mathrm{P}$ into the lipid $P$ was again impaired but the amount of acidsoluble adenine nucleotide in the liver was increased, as was the relative specific activity of the residual $P$ fraction. Further studies on these last 
two changes are in progress. The difficulty in interpreting changes in the radioactivity of the residual $\mathrm{P}$ is discussed by Davidson et al. (1951), particularly in regard to its possible contamination from other fractions. In so far as these results indicate a difference in the responses of the liver and brain they are in agreement with those of Cremer (1957), yet the isolated mitochondria from these tissues are equally sensitive to triethyltin (W. N. Aldridge, personal communication). It would be premature to speculate on the mechanism of these changes which occur in the liver while its temperature is falling.

At the moment these experiments give little help towards understanding the mechanism of action of triethyltin in the whole animal. They do, however, illustrate some of the difficulties which may arise in trying to explain the toxicity of metabolic inhibitors and in trying to correlate studies in vitro with studies in vivo.

\section{SUMMARY}

1. The effect of fatal doses of triethyltin sulphate on the levels of the tissue phosphates and the distribution of injected ${ }^{32} \mathrm{P}$ has been studied in the rat.

2. The plasma inorganic phosphate level rose after triethyltin and this was attributed to a lowered renal function. The specific activity of the plasma inorganic phosphate was higher in the rats treated with triethyltin than in the controls and the penetration of the ${ }^{32} \mathrm{P}$ into the brain was reduced. Its penetration into the liver was unaltered.

3. The phosphate levels in the central nervous system were unaffected by triethyltin except in so far as they were altered by the changes in water content due to the accumulating interstitial oedema. The adenosine triphosphate and diphosphate levels in the liver increased within a few hours of injecting triethyltin.

4. In the central nervous system the relative specific activities of diphosphopyridine nucleotide, the lipid phosphate and the residual phosphate were reduced after triethyltin. In the liver the relative specific activity of the lipid phosphate was also reduced but that of the residual phosphate fraction was increased.

5. These findings are discussed in their relation to the pharmacological effects of triethyltin and the results of previous work in this Laboratory on the action of triethyltin on isolated systems. No conclusion could be reached concerning the mechanism of action of triethyltin in the whole animal but it is thought that the hypothermic action of triethyltin may play an important part in producing the changes observed in the brain.

Our thanks are due to Mr W. R. Lewis of the Tin Research Institute for obtaining a supply of triethyltin sulphate for us and to Miss P. M. Harrison for technical assistance.

\section{REFERENCES}

Aldridge, W. N. (1958). Biochem. J. 69, 367.

Ansell, G. B. \& Dohmen, H. (1956). J. Neurochem. 1, 150. Barnes, J. M. \& Stoner, H. B. (1958). Brit. J. indust. Med. $15,15$.

Berenblum, I. \& Chain, E. (1938)'. Biochem. J. 32, 295.

Bock, R. M., Ling, N. S., Morell, S. A. \& Lipton, S. H. (1956). Arch. Biochem. Biophys. 62, 253.

Bruce, H. M. \& Parkes, A. S. (1949). J. Hyg., Camb., 47, 202.

Bruce, H. M. \& Parkes, A. S. (1956). J. Anim. Tech. Ass. 7, 54.

Buchel, L. \& McIlwain, H. (1950). Nature, Lond., 166, 269.

Caster, H. O., Simon, A. B. \& Armstrong, W. D. (1955). Amer. J. Physiol. 183, 317.

Chaplin, H. (1954). J. Physiol. 123, 22.

Cremer, J. E. (1957). Biochem. J. 67, 87.

Davidson, J. N., Frazer, S. C. \& Hutchison, W. C. (1951). Biochem. J. 49, 311.

Dawson, R. M. C. \& Richter, D. (1950). Proc. Roy. Soc. B, 137, 252.

Fisher, R. A. (1934). Statistical Methods for Research Workers. 5th ed. London: Oliver and Boyd.

Fiske, C. H. \& Subbarow, Y. (1925). J. biol. Chem. 66, 375. Grayson, J. (1952). J. Physiol. 118, 54.

Jolyet, F. \& Cahours, A. (1869). C.R. Acad. Sci., Paris, 68, 1276.

Loomis, W. F. \& Lipmann, F. (1948). J. biol. Chem. 173, 807.

Magee, P. N., Stoner, H. B. \& Barnes, J. M. (1957). J. Path. Bact. 73, 107.

Parker, V. H. (1954). Biochem. J. 57, 381.

Stoner, H. B. (1950). Amer. J. Physiol. 161, 387.

Stoner, H. B. (1954). Brit. J. exp. Path. 35, 487.

Stoner, H. B. (1956). Brit. J. exp. Path. 37, 176.

Stoner, H. B., Barnes, J. M. \& Duff, J. I. (1955). Brit. J. Pharmacol. 10, 16.

Stoner, H. B., Threlfall, C. J. \& Green, H. N. (1952). Brit. J. exp. Path. 33, 398.

Streicher, E. (1956). J. cell. comp. Physiol. 48, 139.

Threlfall, C. J. (1957). Biochem. J. 65, 694.

Webster, G. R. (1954). Biochem. J. 57, 153. 